Research Article

\title{
Impact of health education intervention on consumption of iodised salt in school children in Aligarh, India
}

\author{
Mohammad A. Ansari*, Zulfia Khan \\ Department of Community Medicine, J.N. Medical College, A.M.U., Aligarh, India
}

Received: 21 March 2016

Accepted: 26 April 2016

\section{*Correspondence:}

Dr. Mohammad A. Ansari,

E-mail: atharansari777@ rediffmail.com

Copyright: $\odot$ the author(s), publisher and licensee Medip Academy. This is an open-access article distributed under the terms of the Creative Commons Attribution Non-Commercial License, which permits unrestricted non-commercial use, distribution, and reproduction in any medium, provided the original work is properly cited.

\begin{abstract}
Background: Iodine deficiency is one of the most neglected and wide spread of all nutritional deficiencies, constituting a real brake on human development. Deficiency of iodine may result in development of goitre and other IDD. Objective is to find out the impact of health education intervention on awareness of iodine content and consumption of iodized salt in school children.

Methods: This study was conducted among school children of $1^{\text {st }}$ to $5^{\text {th }}$ standard (6-12 years). After one year of health education intervention package, 200 children were included from one affluent and one non-affluent school in Aligarh. Improvement in awareness regarding iodine content of salt was assessed. Iodine content of salt, consumed by children was analyzed using the spot testing kit. Statistical analysis was done using SPSS version 20.

Results: In pre-intervention group, awareness regarding iodised salt was only $26.3 \%$ which rose to $83.5 \%$. After intervention, consumption of salt with $>15 \mathrm{ppm}$ iodine content was increased from $16.1 \%$ to $48.3 \%$. Consequently consumption of salt with nil iodine declined from $25.0 \%$ to $8.1 \%$.

Conclusions: It may be concluded that after the intervention package, awareness level improved and consequently, consumption of adequately iodized salt ( $>15 \mathrm{ppm}$ iodine) also improved. Sustained IEC (Information, Education and Communication) activities should be carried out more vigorously in schools and community so that people are made aware about the benefits of consumption of iodated salt.
\end{abstract}

Keywords: Iodine deficiency, Iodised salt, Awareness, Health education

\section{INTRODUCTION}

Iodine deficiency is so easy to prevent that it is a crime to let a single child be born mentally handicapped for the reason. Labouisse H, Executive Director, UNICEF 1978.

Iodine deficiency is one of the most neglected and wide spread of all nutritional deficiencies, constituting a real brake on human development.

Iodine is required for the synthesis of thyroxin (T4) and triiodothyronine (T3), very important in the regulation of the metabolism of proteins, carbohydrates and fats and in almost all the activities of the body.

Two most recognized features of iodine deficiency in the past like endemic goitre and cretinism are the tip of the Iodine deficiency disorders (IDD) iceberg. Certainly there are other consequences of iodine deficiency which affect the fetus, the neonate, the infant, the child, the adolescent and the adult in the whole population in the form of abortions, still births, neonatal goitre, brain damage (cretinism), impaired school performance, retarded physical development, impaired mental function and features of hypothyroidism which include weight gain, increased cold intolerance, lethargy, easy 
fatigability, menstrual irregularities, hoarseness of voice and hair loss etc.

As far as the magnitude of the problem is concerned, the countries of South East Asia present a particularly urgent challenge for the control of IDD. Many countries in South East Asia have IDD as a significant health problem. According to World Health Organization (WHO), iodine deficiency occurs in 130 countries around the world, and 2.2 billion people (38\% of the world's population) live in iodine deficient areas. ${ }^{1}$

In India, IDD has been identified as a public health problem. It has been observed that the world's most intense goitre belt is in India stretching $2400 \mathrm{Kms}$ from Kashmir in the North West to the Naga Hills in the East. In addition to the known Himalayan endemic belt, iodine deficiency and endemic goitre has been reported from many other states in the country as well. Surveys conducted in India have revealed that out of the 325 districts surveyed in India, 263 districts are IDDendemic, i.e. the prevalence of IDD is above 10 per cent in the population, and more than 200 million are at risk of IDD. ${ }^{2,3}$ WHO has recommended that for assessment of Iodine deficiency in an area, children in the age group 6 12 years should be surveyed. ${ }^{4}$

After trying many methods, salt emerges as the best vehicle for iodine supplementation. After iodisation of salt, it is to be made mandatory that it should contain 30 parts per million (ppm) iodine at the manufacturer level and $15 \mathrm{ppm}$ at distribution channel including consumer level.

If salt with recommended level of iodine is consumed by a community for just 12 months, no more cretins will be born, no more babies will suffer from retarded physical or mental development attributed to iodine deficiency.

School children have been identified as a cost effective source of improving consumption of iodised salt in the community by many researchers.

Objective is to carryout training and health education sessions at multiple settings and to evaluate its impact on awareness regarding iodized salt and its consumption in school children.

\section{METHODS}

The present study was conducted among school children (6-12 years) in Aligarh. School children were chosen for the study because they are highly vulnerable to IDD, representative of the community and easily accessible.

Aligarh is situated in Western part of Uttar Pradesh about $133 \mathrm{Kms}$ southeast of Delhi on the Delhi - Kolkata railway line and Grand Trunk Road. The latitude is $27.88^{\circ}$ North and $78.08^{\circ}$ east. The city is in the middle portion of the Doab, the land between the Ganges and the Yamuna rivers.

The population of Aligarh district is $3,673,849$. It has a sex ratio of 876 females for every 1000 males and a literacy rate of $69.61 \% .^{5}$

The study was carried out in schools of Aligarh where permission was granted.

\section{Sampling unit}

$1^{\text {st }}$ to $5^{\text {th }}$ standard schools children (age group 6-12 years) were the sampling units for study conducted in schools. This is the preferred group as it is usually accessible. There is a practical reason for not measuring very young age groups. The smaller the child, the smaller the thyroid, and more difficult it is to perform palpation. ${ }^{4}$ In the selected schools, almost every child of $1^{\text {st }}$ standard had completed six years of age and most of the children of $5^{\text {th }}$ standard were completing twelve years of age.

\section{Study duration}

The data were collected over a period of four years from $1^{\text {st }}$ January 2009 to $31^{\text {st }}$ December 2013. Different schools were approached over this period of time as per convenience of the investigator and school authorities.

Sample size: Directorate General of Health Services found a goitre prevalence rate of $12 \%$ in Aligarh District.6 This prevalence of goitre was used for calculating the minimum sample size in our study. ${ }^{7}$ Taking the value of prevalence ' $p$ ' as $12 \%$ and relative error (1) $20 \%$ of ' $p$ ', the sample size $(N)$ was calculated as: ${ }^{8}$

$$
\mathrm{N}=4 \times \mathrm{p} \times \mathrm{q} / 12
$$

Where $\mathrm{p}(\%)=$ prevalence, $\mathrm{q}(\%)=100-\mathrm{p}$,

$1=$ relative error

$$
\mathrm{N}=4 \times 12 \times 88 /(0.2 \times 12) 2
$$

$\mathrm{N}=733$

Taking into consideration $20 \%$ non-response / non cooperation rate, the above sample size was increased by $20 \%$ then the total sample size was:

$\mathrm{N}=733+(0.2 \times 733)$

$\mathrm{N}=879$

However, a total of 950 subjects were included in the study. 
To promote the consumption of iodized salt in the schools, health education sessions were organized in all selected schools of Aligarh (Figure 1). Schools were contacted several days before the study began to inform the principals of the schools, the study purpose and to get consent from them as well as parents/guardians of children. In consultation with principal, a suitable date (a day on which the attendance in the school was maximum, preferably early in the week, avoiding national and state holidays), time and place for interviewing and examining the children were chosen. As a part of ethical considerations, they were briefed about presentation of IDD, and its consequences and methods available for its prevention especially health benefits of taking iodised salt in diet, food items which prevent the utilization of iodine in the body. This helped us having their maximum participation for conducting the study in school children and it also ensured good attendance of students.

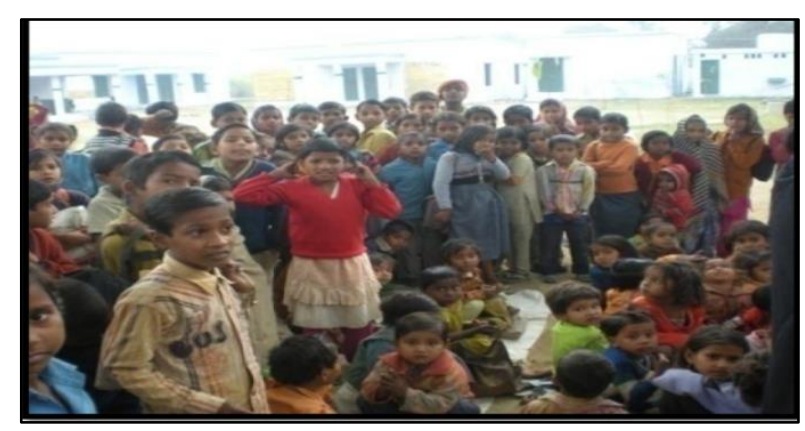

Figure 1: Health education session in a school Aligarh.

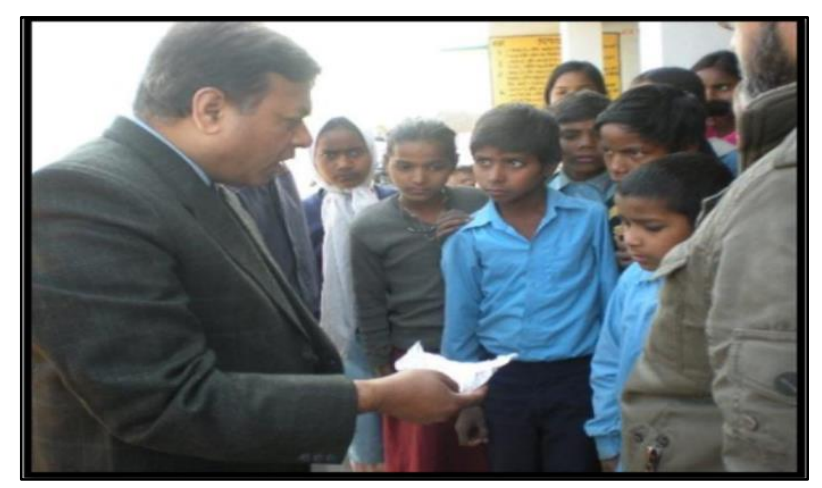

Figure 2: Salt testing in a school Aligarh.

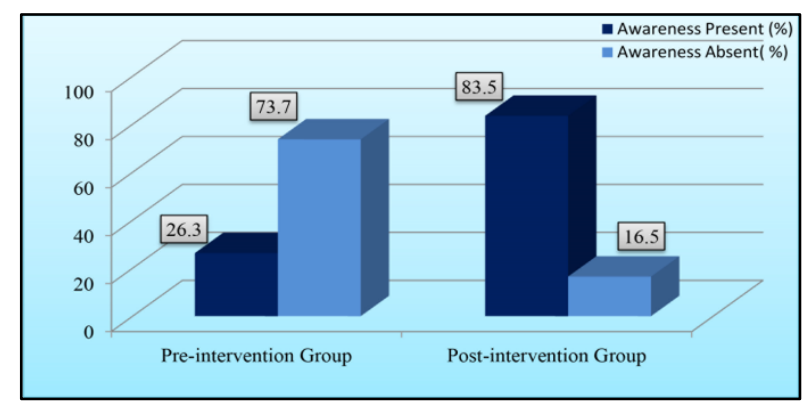

Figure 3: Impact of intervention on awareness regarding iodised salt.
After one year of counseling, 200 children were selected randomly from within the sample from two schools (Krishna International and Green Fields Public schools) i.e. one affluent (having tuition fees more than Rs. 10,000/annum), and one non-affluent schools (having tuition fees less than Rs. 10,000/annum), in Aligarh to assess the impact of health education and counseling. Type of school was used as a proxy for socio-economic status. These students were selected to find out the impact of intervention package on consumption of iodized salt, if any. Students were asked to disseminate this information in their families and friends.

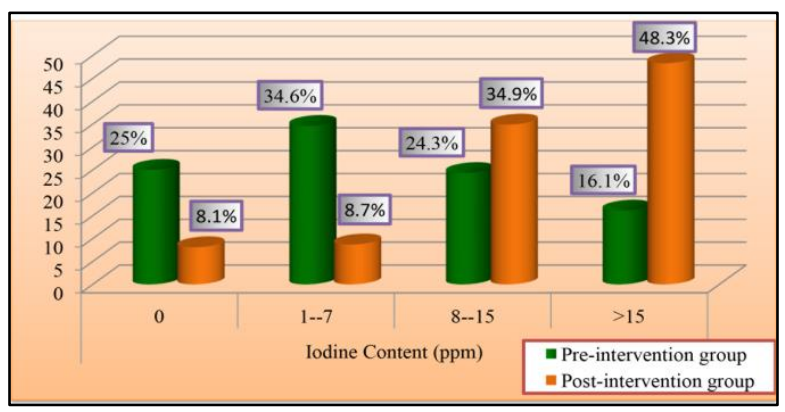

Figure 4: Impact of intervention on quality of salt consumed.

Every child was asked to bring approximately two teaspoons $(10 \mathrm{gm})$ of salt being used for cooking in their respective households, in labeled auto sealed polythene pouches. For community or population surveys, $10 \mathrm{gm}$ salt samples are sufficient. ${ }^{4}$ Iodine content of salt samples was tested using the spot testing kit (STK) in the school in front of students and teachers (Figure 2). This method is similar with National Family Health Survey (NFHS) estimates conducted in the year 2005-06. ${ }^{9}$ Tests using STK provide qualitative information on iodine content of salt samples. It estimates the percent of households using salt with no iodine, but will not provide accurate information on the percent using adequately iodized salt, or information on salt with excessive iodine. ${ }^{4}$ Data was analyzed using statistical package SPSS version 20. Chi square test and other statistical methods were applied wherever applicable.

\section{Ethical issues}

Permission was taken from principals of all the schools included in our study. Approval of Institutional Ethics and Research Advisory Committee, Faculty of Medicine, J.N. Medical College, A.M.U., Aligarh was also taken. Informed written consent was taken from the child's parents/guardians. Concerned authorities were also informed about the study. Confidentiality was assured. Interviews were conducted in a non-hostile and nonjudgmental manner. Those found to have goiter and other diseases were referred to nearby health centres or J.N. Medical College Hospital for further evaluation and management. If a subject was found to have any other 
complaint, proper treatment or advice was given by the investigator.

\section{RESULTS}

As shown in Table 1, in pre-intervention group, awareness regarding iodised salt was only $26.3 \%$ which rose to $83.5 \%$ after health education intervention carried out in both the schools. This increase was more marked in Krishna International School where the level of awareness went up from $14.4 \%$ to $83.0 \%$ (Figure 3).

Table 1: Awareness in schools regarding iodized salt.

\begin{tabular}{|c|c|c|c|c|c|c|c|}
\hline \multirow[t]{3}{*}{$\begin{array}{l}\text { S. } \\
\text { No. }\end{array}$} & \multirow[t]{3}{*}{ Schools } & \multicolumn{4}{|c|}{$\begin{array}{l}\text { Awareness regarding } \\
\text { iodized salt }\end{array}$} & \multirow{2}{*}{\multicolumn{2}{|c|}{ Total }} \\
\hline & & \multicolumn{2}{|c|}{ Present } & \multicolumn{2}{|c|}{ Absent } & & \\
\hline & & No. & $\%$ & No. & $\%$ & No. & $\%$ \\
\hline \multicolumn{8}{|c|}{ Pre-intervention } \\
\hline 1. & $\begin{array}{l}\text { Green } \\
\text { Fields }\end{array}$ & 54 & 43.5 & 70 & 56.5 & 124 & 40.8 \\
\hline 2. & $\begin{array}{l}\text { Krishna } \\
\text { Intern. }\end{array}$ & 26 & 14.4 & 154 & 85.6 & 180 & 59.2 \\
\hline Tota & & 80 & 26.3 & 224 & 73.7 & 304 & 100.0 \\
\hline \multicolumn{8}{|c|}{ Post-intervention } \\
\hline 1. & $\begin{array}{l}\text { Green } \\
\text { Fields }\end{array}$ & 84 & 84.0 & 16 & 16.0 & 100 & 50.0 \\
\hline 2. & $\begin{array}{l}\text { Krishna } \\
\text { Intern. }\end{array}$ & 83 & 83.0 & 17 & 17.0 & 100 & 50.0 \\
\hline Total & & 167 & 83.5 & 33 & 16.5 & 200 & 100.0 \\
\hline
\end{tabular}

As shown in Table 2, in the pre-intervention group, out of 292 samples collected in 304 students, 73 (25.0\%) samples were having nil iodine content and only $16.1 \%$ students were consuming salt with $>15$ ppm iodine content.
In post-intervention group, consumption of salt with $>15$ ppm iodine content increased significantly from $16.1 \%$ to $48.3 \%$. This increase was observed in both the schools. In Green Fields School, it jumped from $13.0 \%$ to $41.7 \%$ while an increase from $18.1 \%$ to $54.6 \%$ was noticed in Krishna International School (Figure 4). When iodine content of $<15$ and $>15 \mathrm{ppm}$ of salt samples collected in two schools, was analysed in pre and post intervention groups, highly significant statistical difference was found.

Table 3 shows the level of awareness regarding iodine content of salt and quality of salt consumed in both pre and post-intervention groups in schools. In preintervention group, majority of the students were taking salt with 1-7 ppm iodine content $(34.6 \%)$ followed by salt with nil iodine $(25.0 \%)$. Out of 77 students, who were aware of importance of iodised salt in diet, only $16.9 \%$ were taking salt of iodine content of $>15 \mathrm{ppm}$ while $29.9 \%$ were consuming salt with nil iodine.

In post intervention group, level of awareness markedly improved to $83.7 \%$ from $26.4 \%$. After intervention package, consumption of iodised salt with $>15 \mathrm{ppm}$ iodine content rose to $48.3 \%$ from $16.1 \%$ in both the schools. Consequently consumption of salt with nil iodine declined from $25.0 \%$ to $8.1 \%$. When consumption of salt with iodine content of $<15$ and $>15 \mathrm{ppm}$ in students who were aware in pre and post intervention groups, was analysed, a highly significant statistical difference was found $(\chi 2=41.8-\mathrm{d} . \mathrm{f}=1 \mathrm{p}<.001)$.

Knowledge about a disease and its risk factors is the first step towards prevention. Knowledge of the problem of IDD has spread extensively as a multisectoral activity through mass communication, schools, and community participation.

Table 2: School and quality of salt consumed (Iodine content).

\begin{tabular}{|c|c|c|c|c|c|c|c|c|c|c|c|}
\hline \multirow{3}{*}{ S. No. } & \multirow{3}{*}{ Schools } & \multicolumn{8}{|c|}{ Iodine content (ppm) } & \multirow{2}{*}{\multicolumn{2}{|c|}{ Total }} \\
\hline & & 0 & & $1-7$ & & $8-15$ & & $>15$ & & & \\
\hline & & No. & $\%$ & No. & $\%$ & No. & $\%$ & No. & $\%$ & No. & $\%$ \\
\hline \multicolumn{12}{|c|}{ Pre-intervention } \\
\hline 1. & Green Fields & 40 & 34.8 & 33 & 28.7 & 27 & 23.5 & 15 & 13.0 & 115 & 39.4 \\
\hline 2. & $\begin{array}{l}\text { Krishna } \\
\text { Intern. }\end{array}$ & 33 & 18.6 & 68 & 38.4 & 44 & 24.9 & 32 & 18.1 & 177 & 60.6 \\
\hline Total & & 73 & 25.0 & 101 & 34.6 & 71 & 24.3 & 47 & 16.1 & 292 & 100.0 \\
\hline \multicolumn{12}{|c|}{ Post-intervention } \\
\hline 1. & Green Fields & 10 & 11.9 & 6 & 7.1 & 33 & 39.3 & 35 & 41.7 & 84 & 48.8 \\
\hline 2. & $\begin{array}{l}\text { Krishna } \\
\text { Intern. }\end{array}$ & 4 & 4.5 & 9 & 10.2 & 27 & 30.7 & 48 & 54.6 & 88 & 51.2 \\
\hline Total & & 14 & 8.1 & 15 & 8.7 & 60 & 34.9 & 83 & 48.3 & 172 & 100.0 \\
\hline
\end{tabular}

$\left(\chi^{2}=55.5\right.$, d.f. $\left.=1 ; \mathrm{p}<.001\right)$

In a study conducted in Turkey, significant difference in the pre and post intervention findings was observed. Prevalence of iodized salt consumption was $54.5 \%$. Following the 3-month education program it increased to $62.4 \%$. The results clearly showed that the health education intervention was effective in improving the use of iodized salt. ${ }^{11}$

The NFHS-2 (2000) showed a lack of awareness among people with regard to the benefits of iodized salt. ${ }^{10}$ 
To know the impact of awareness and practice of proper consumption of iodized salt, a longitudinal educational interventional study was conducted in children of 8-12 years age group in rural primary schools of Kolkata. It was found that school children were very effective at transmitting the health education to the parents and significant change was observed in their practice as well. $^{12}$

It was also observed in Dharwad, Karnataka that imparting nutrition education was important to promote consumption of iodized salt to prevent IDD. ${ }^{13}$

Table 3: Awareness and quality of salt consumed.

\begin{tabular}{|c|c|c|c|c|c|c|c|c|c|c|}
\hline \multirow[t]{3}{*}{ S. No. Awareness } & \multicolumn{8}{|c|}{ Iodine content (ppm) } & \multirow{2}{*}{\multicolumn{2}{|c|}{ Total }} \\
\hline & 0 & & $1-7$ & & $8-1$ & & $>15$ & & & \\
\hline & No. & $\%$ & No. & $\%$ & No. & $\%$ & No. & $\%$ & No. & $\%$ \\
\hline \multicolumn{11}{|l|}{ Pre-intervention } \\
\hline 1. Present & 23 & 29.9 & 23 & 29.9 & 18 & 23.4 & 13 & 16.9 & 77 & 26.4 \\
\hline Absent & 50 & 23.3 & 78 & 36.3 & 53 & 24.7 & 34 & 15.8 & 215 & 73.6 \\
\hline Total & 73 & 25.0 & 101 & 34.6 & 71 & 24.3 & 47 & 16.1 & 292 & 100.0 \\
\hline \multicolumn{11}{|l|}{ Post-intervention } \\
\hline 1. Present & 12 & 8.3 & 11 & 7.6 & 53 & 36.8 & 68 & 47.4 & 144 & 83.7 \\
\hline Absent & 2 & 7.1 & 4 & 14.3 & 7 & 25.0 & 15 & 53.6 & 28 & 16.3 \\
\hline Total & 14 & 8.1 & 15 & 8.7 & 60 & 34.9 & 83 & 48.3 & 172 & 100.0 \\
\hline
\end{tabular}

$\left(\chi^{2}=41.8\right.$, d.f. $\left.=1, \mathrm{p}<.001\right)$.

\section{DISCUSSION}

School children have been identified as a cost effective source of improving consumption of iodised salt in the community by many researchers. School children were chosen for the study because they are highly vulnerable to IDD, representative of the community and easily accessible. There is a practical reason for not measuring very young age groups. The smaller the child, the smaller the thyroid, and more difficult it is to perform palpation

After one year of counseling, 200 children were selected randomly from within the sample from two schools (Krishna International and Green Fields Public schools) i.e. one affluent (having tuition fees more than Rs. 10,000/annum), and one non-affluent schools (having tuition fees less than Rs. 10,000/annum), in Aligarh to assess the impact of health education and counseling. Type of school was used as a proxy for socio-economic status. These students were selected to find out the impact of intervention package on consumption of iodized salt, if any. Students were asked to disseminate this information in their families and friends.

After health education intervention carried out in both the schools, there was marked improvement in the level of awareness regarding iodised salt.

There was significant increase in consumption of powdered salt as compared to crystalline (pebble) salt after intervention. Crystalline form of salt could be used as powdered salt but conventionally powdered salt was packed salt available in the market under different brand names.
For better assessment of outcome of intervention package, change in quality of salt, consumed was studied. Improvement in quality of salt was assessed by the consumption of salt having $>15 \mathrm{ppm}$ iodine content in both the schools.

Consumption of salt with $>15$ ppm iodine content was increased significantly from. This increase was observed in both the schools. In Green Fields School, it jumped from $13.0 \%$ to $41.7 \%$ while an increase from $18.1 \%$ to $54.6 \%$ was noticed in Krishna International School.

Before intervention, majority of the students were taking salt with 1-7 ppm iodine content followed by salt with nil iodine. Students, who were aware of importance of iodised salt in diet, only $16.9 \%$ were taking salt of iodine content of $>15 \mathrm{ppm}$ while $29.9 \%$ were consuming salt with nil iodine.

In post intervention group, level of awareness markedly improved to $83.7 \%$ from $26.4 \%$. After intervention package, consumption of iodised salt with $>15 \mathrm{ppm}$ iodine content rose to $48.3 \%$ from $16.1 \%$ in both the schools. Consequently consumption of salt with nil iodine declined from $25.0 \%$ to $8.1 \%$.

\section{CONCLUSION}

At last, it is concluded that if all salt is iodized adequately and all families use only iodized salt, iodine deficiency will no longer threaten the health and development of children. This will help building a healthy society and nation. 
Sustained IEC (Information, Education and Communication) activities should be carried out more vigorously in schools and community so that people are made aware about the benefits of consumption of iodated salt.

Funding: No funding sources Conflict of interest: None declared

Ethical approval: The study was approved by the Institutional Ethics Committee

\section{REFERENCES}

1. Benoist BD, McLean E, Andersson M, Rogers L. Iodine deficiency in 2007: global progress since 2003. Food Nutr Bull. 2008;29:195-202.

2. Department of health and family welfare. Annual report 2010-2011. New Delhi: Ministry of Health and Family Welfare, Government of India; 2011. Available at: http://www.mohfw.nic.in/ showfile.php?lid=767, Accessed on 03.06.2015.

3. National iodine deficiency disorders control programme (NIDDCP). Revised Policy Guidelines, New Delhi: DGHS, Ministry of Health and Family Welfare, Government of India, 2006. Available at: http://www.childhealthindiainfo.com/index.php?q=c ontent/government-policy-revised-policyguidelines-national-iodine-deficiency-disorderscontrol-pro. Accessed on 14.12.2015.

4. World Health Organization. Vitamin and mineral nutrition information system (VMNIS): database on iodine deficiency. World Health Organization 2007. Available at :http://www.who.int/ vmnis/iodine/ status/summary/IDD_estimates_table_2007.pdf Accessed on 26.04.15.

5. Census 2011. Provisional population totals paper 1 of 2011 india series 1 . New Delhi: office of registrar general and census commissioner. Ministry of home affairs, government of India 2011. Available at: http://www.censusindia.gov.in/2011-prov-results/ data_files/india/Final\%20PPT\%202011_chapter3.pd f. Accessed on 18.05.2015.
6. Directorate General of Health Services, Govt. of India. National Goitre Control Programme. Prevalence rate of goitre according to survey conducted in areas during 1981-2003. 1995.

7. Kapil U, Sharma TD, Singh P. Iodine status and goitre prevalence after 40 years of salt iodization in the kangra district, India. Indian $\mathbf{J}$ Pediatr. 2007;74:135-7.

8. Rao PSSS, Richard J. Introduction to biostatistics and research methods, $4^{\text {th }}$ Ed. P H I Learning Private Limited, New Delhi. 2009;195.

9. National Family Health Survey (NFHS-3) 2005-06. International institute for population sciences (IIPS) and macro international, 2007. Volume I. Ministry of Health and Family Welfare, Government of India. Mumbai. Available at: usaid.gov/pdf_docs/ PNADK385.pdf. Accessed on 12.10.15.

10. National Family Health Survey (NFHS-2) 1998-99. International institute for population sciences (IIPS), 2000. Ministry of Health and Family Welfare, Government of India. Mumbai. Available from: http://www.nfhsindia. org/india2.html. Accessed on 12.10.15.

11. Can G, Okten A, Green J. The role of local mass media in promoting the consumption of iodized table salt. Health Education Research. 2001;16 (5):603-7.

12. Aikat A, Mondal A. Total goitre rate in rural primary school children aged 8-12 years and impact of their health education on consumption of iodized salt among their families. J Indian Med Assoc. 2011;109:174-6.

13. Aruna RT, Sarojani JK, Devendrappa S, Lata P. Impact of education intervention on prevention of iodine deficiency disorder in Dharwad Taluk, Karnataka. International Journal of Farm Sciences. 2013;3(1):156-63.

Cite this article as: Ansari MA, Khan Z. Impact of health education intervention on consumption of iodised salt in school children in Aligarh, India. Int J Communitv Med Public Health 2016:3:1431-6. 